\title{
Abnormal dynamics of growth hormone after thyrotropin-releasing hormone loading test, gonadotropin-releasing hormone loading test, and oral glucose tolerance test in mixed gonadal dysgenesis with a pituitary lesion
}

\author{
Akira Matsuno, So Yamada, Shoko M Yamada \\ Hiroshi Nakaguchi, Katsumi Hoya, Mineko Murakami
}

\begin{abstract}
Introduction: In mixed gonadal dysgenesis or $\mathrm{X} / \mathrm{XY}$ gonadal dysplasia, the axis of hypothalamus-pituitary-reproductive organ is usually maintained. Case Report: We report a 29-year-old woman of mixed gonadal dysgenesis with abnormal growth hormone (GH) dynamics after thyrotropin-releasing hormone loading test, gonadotropin-releasing hormone loading test, and oral glucose tolerance test and a pituitary lesion. Conclusion: The abnormal dynamics of pituitary hormone, especially GH, and the existence of a pituitary lesion in mixed gonadal dysgenesis is a rare event.
\end{abstract}

Keywords: Mixed gonadal dysgenesis, $\mathrm{X} / \mathrm{XY}$ gonadal dysplasia, Growth hormone,

Matsuno $A^{1}$, Yamada $S^{1}$, Yamada $S M^{1}$, Nakaguchi $H^{1}$, Hoya $\mathrm{K}^{1}$, Murakami $\mathrm{M}^{1}$

Affiliations: ${ }^{1}$ Department of Neurosurgery, Teikyo University Chiba Medical Center, 3426-3 Anesaki, Ichihara City, Chiba 299-0111, Japan.

Corresponding Author: Akira Matsuno, Department of Neurosurgery, Teikyo University Chiba Medical Center, 3426-3 Anesaki, Ichihara City, Chiba 299-0111, Japan; Phone: 81-436-62-1211 ext. 2621; Fax: 81-436-62-1357; E-mail: akirakun@med.teikyo-u.ac.jp

Received: 20 October 2010

Accepted: 16 January 2011

Published: 25 January 2011
Amenorrhea, Silent pituitary somatotroph adenoma

Matsuno A, Yamada S, Yamada SM, Nakaguchi H, Hoya K, Murakami M. Abnormal dynamics of growth hormone after thyrotropin-releasing hormone loading test, gonadotropin-releasing hormone loading test, and oral glucose tolerance test in mixed gonadal dysgenesis with a pituitary lesion. International Journal of Case Reports and Images 2011;2(1):12-14.

$$
* * * * * * * * * \text {. }
$$

doi:10.5348/ijcri-2011-01-15-CR-3

\section{INTRODUCTION}

The mixed gonadal dysgenesis or $\mathrm{X} / \mathrm{XY}$ gonadal dysplasia in a woman is one of the major issues related to primary amenorrhea. The axis of hypothalamus-pituitary-reproductive organ is usually maintained in this disease. An abnormal dynamics of growth hormone $(\mathrm{GH})$, and the existence of a pituitary lesion in mixed gonadal dysgenesis has not been reported previously. We present the endocrinological characteristics of a patient with mixed gonadal dysgenesis who had a pituitary lesion and abnormal dynamics of GH.

\section{CASE REPORT}

A 29-year-old woman was admitted to Teikyo 
University Chiba Medical Center with a complaint of amenorrhea. Physical examination revealed neither acromegaloid nor Cushingoid features. Basal levels of serum GH on admission were elevated, ranging from 0.81 to $7.26 \mathrm{ng} / \mathrm{ml}$ (normal range: $0.66-3.68$ ), whereas basal levels of prolactin (PRL) were within normal ranges, being 12.7-17.5 ng/ml (normal range: 6.1230.5). Insulin-like growth factor (IGF-1) level ranged from 320 to $370 \mathrm{ng} / \mathrm{ml}$ (normal range: $119-389$ for woman of this age). The thyroid function was normal with free triiodothyronine (T3) $3.05 \mathrm{pg} / \mathrm{ml}$ (normal range: 2.30-4.30), free thyroxine (T4) $1.07 \mathrm{ng} / \mathrm{dl}$ (normal range: 0.90-1.70) and thyroid hormone stimulating hormone (TSH) $4.60 \mathrm{mIU} / \mathrm{ml}$ (normal range: $0.50-5.00$ ). An oral glucose tolerance test (OGTT) showed no apparent suppression of GH, being $7.17,6.38,7.09,6.03,4.20$ and $0.77 \mathrm{ng} / \mathrm{ml}$, at $0,15,30$, 60,90 and $120 \mathrm{~min}$ after loading. Thyrotropinreleasing hormone (TRH) provocation test showed paradoxical rise of serum $\mathrm{GH}$, being 2.13, 3.51, 4.06, $11.7,3.14$ and $1.94 \mathrm{ng} / \mathrm{ml}$ at $\mathrm{o}, 15,30,60,90$ and 120 min after loading. Gonadotropin-releasing hormone (GnRH) stimulation test showed paradoxical rise of serum GH, being $0.39,3.32,12.5,9.91,3.21$ and 0.75 $\mathrm{ng} / \mathrm{ml}$ at $\mathrm{o}, 15,30,60,90$ and 120 min after loading. Growth hormone releasing hormone (GHRH) provocation test showed no reactive secretion of GH. The serum GH level was not suppressed by $2.5 \mathrm{mg}$ of bromocriptine, being $0.22,0.52,13.2,7.89,1.96,4.96$ and $7.96 \mathrm{ng} / \mathrm{ml}$ after $0,1,2,4,8,12$ and $24 \mathrm{hrs}$ after loading, whereas serum PRL was suppressed by $2.5 \mathrm{mg}$ of bromocriptine, being 17.5, 7.35, 3.04, 1.50, 1.09, 1.43 and $4.24 \mathrm{ng} / \mathrm{ml}$ after $0,1,2,4,8,12$ and $24 \mathrm{hrs}$ after loading. Serum follicle-stimulating hormone (FSH) and luteinizing hormone (LH) were elevated to 77.2
$\mathrm{IU} / \mathrm{ml}$ (normal range: 5.2-14.4), and $34.7 \mathrm{mIU} / \mathrm{ml}$ (normal range: 1.8-7.6), respectively. GnRH provocation test revealed no reactive rises of $\mathrm{FSH}$, being $77.2,83.5,96.1,96.5,97.2$ and $97.8 \mathrm{mIU} / \mathrm{ml}$ at $\mathrm{o}$, $15,30,60,90$ and 120 min after loading, whereas LH was slightly elevated, being $34.7,81.4,86.0,86.6,76.8$ and $73.9 \mathrm{mIU} / \mathrm{ml}$ at $0,15,30,60,90$ and $120 \mathrm{~min}$ after loading. Magnetic resonance imaging (MRI) revealed a low signal intensity lesion that was less enhanced by gadolinium diethylenetriamine pentaacetic acid (GdDTPA) in pituitary gland, which suggested the presence of a pituitary adenoma (Figure 1).

These studies suggested that the patient had primary amenorrhea with abnormal dynamics of $\mathrm{GH}$ and a pituitary lesion. Gynecological studies revealed bilateral fibrous ovaries. Chromosomal analysis of peripheral white blood cell (G-banding) disclosed mosaic chromosomes of $47 \mathrm{XXY}$ and $45 \mathrm{X}$, which suggested that the patient had $\mathrm{X} / \mathrm{XY}$ gonadal dysplasia. The fibrous ovaries were surgically removed for prophylaxis of gonadal tumors.

\section{DISCUSSION}

Mixed gonadal dysgenesis or $\mathrm{X} / \mathrm{XY}$ gonadal dysplasia in a woman is one of the major issues related to primary amenorrhea. The first step of differential diagnosis of patients with amenorrhea is the discrimination of primary or secondary amenorrhea. The elevated serum FSH and LH levels suggest that the patient has primary amenorrhea. However, when the patient has abnormality in pituitary hormone
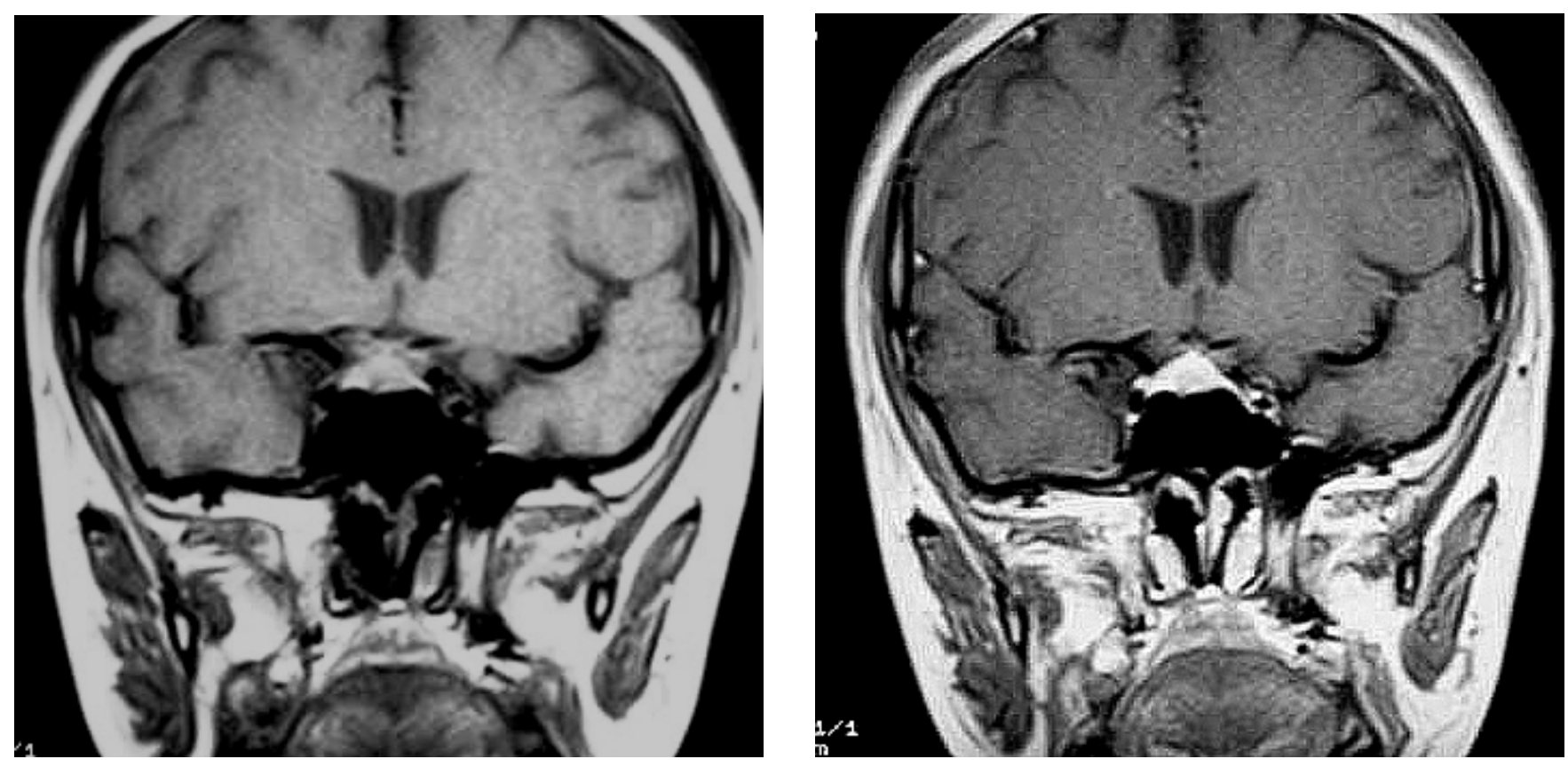

Figure 1: Magnetic resonance imaging revealed a low signal intensity lesion (left) that was less enhanced by gadolinium diethylenetriamine pentaacetic acid in pituitary gland (right), which suggested the presence of a pituitary adenoma. 
secretion, as shown in the present case, this condition may be somewhat confusing, because hyperprolactinemia, abnormal dynamics of $\mathrm{GH}$, and the presence of pituitary lesion may derange menstrual rhythm.

In mixed gonadal dysgenesis or $\mathrm{X} / \mathrm{XY}$ gonadal dysplasia, the axis of hypothalamus-pituitaryreproductive organ is usually maintained. The cause of the abnormal dynamics of $\mathrm{GH}$ in this case cannot be determined. Nevertheless, it may be evoked by a GHsecreting adenoma, although the pathology of pituitary lesion is not verified. Clinically silent somatotroph adenoma has been reported by several investigators, and this condition frequently has menstrual disorder [1-10].

\section{CONCLUSION}

The abnormal dynamics of pituitary hormone, especially GH, and the existence of a pituitary lesion in mixed gonadal dysgenesis or $\mathrm{X} / \mathrm{XY}$ gonadal dysplasia is a rare event.

\section{$* * * * * * * * *$}

\section{Author Contributions}

Akira Matsuno - Conception and design, Acquisition of data, Analysis and interpretation of data, Drafting the article, Critical revision of the article, Final approval of the version to be published

So Yamada - Conception and design, Acquisition of data, Analysis and interpretation of data, Critical revision of the article, Final approval of the version to be published

Shoko M. Yamada - Conception and design, Acquisition of data, Analysis and interpretation of data, Drafting the article, Critical revision of the article, Final approval of the version to be published Hiroshi Nakaguchi - Conception and design, Acquisition of data, Analysis and interpretation of data, Critical revision of the article, Final approval of the version to be published

Katsumi Hoya - Conception and design, Acquisition of data, Analysis and interpretation of data, Drafting the article, Critical revision of the article, Final approval of the version to be published

Mineko Murakami - Conception and design, Acquisition of data, Analysis and interpretation of data, Critical revision of the article, Final approval of the version to be published

\section{Guarantor}

The corresponding author is the guarantor of submission.

\section{Conflict of Interest}

Authors declare no conflict of interest.

\section{Copyright}

(C) Akira Matsuno et. al. 2010; This article is distributed under the terms of Creative Commons attribution 3.0 License which permits unrestricted use, distribution and reproduction in any means provided the original authors and original publisher are properly credited. (Please see www.ijcasereportsandimages.com /copyright-policy.php for more information.)

\section{REFERENCES}

1. Kageyama K, Nigawara T, Kamata Y, Takahashi T, Anzai J, Suzuki S et al. A case of macroprolactinoma with subclinical growth hormone production. Endocr J 2002;49:41-47.

2. Kobayashi I, Oka H, Naritaka H, Sato Y, Fujii K, Kameya T. Expression of Pit-1 and growth hormone-releasing hormone receptor mRNA in human pituitary adenomas: difference among functioning, silent, and other nonfunctioning adenomas. Endocr Pathol 2002;13:83-98.

3. Matsuno A, Sanno N, Tahara S. Teramoto A, Osamura RY, Wada $\mathrm{H}$ et al. Silent somatotroph adenoma, detected by catalyzed signal amplification and non-radioisotopic in situ hybridization. Endocr J 1999;46[Suppl]:S81-84.

4. Matsuno A, Ogino $\mathrm{Y}$, Itoh J, Osamura RY, Nagashima T. Detection of a silent pituitary somatotroph adenoma in a patient with amenorrhea and/or galactorrhea: paradoxical response of GH in TRH or GnRH provocation test. Endocr J 2000;47[Suppl]:S105-109.

5. Matsuno A, Ogino Y, Katayama H, Osamura RY, Nagashima T. Identification of a silent pituitary somatotroph adenoma based on paradoxical response of growth hormone on a thyrotropinreleasing hormone or gonadotropin-releasing hormone provocation test. Am J Obstet Gynecol 2001;184:286-288.

6. Matsuno A, Itoh J, Itoh Y, Osamura RY, Katayama $\mathrm{H}$, Nagashima T. Histopathological analyses of silent pituitary somatotroph adenomas using immunohistochemistry, in situ hybridization and confocal laser scanning microscopic observation. Pathol Res Pract 2001;197:13-20.

7. Naritaka H, Kameya T, Sato Y, Furuhata S, Otani M, Kawase T. Morphological characterization and subtyping of silent somatotroph adenomas. Pituitary 1999;1:233-241.

8. Sakharova AA, Dimaraki EV, Chandler WF, Barkan AL. Clinically silent somatotropinomas may be biochemically active. J Clin Endocrinol Metab 2005;90:2117-2121.

9. Tourniaire J, Trouillas J, Chanlendar D, BonnetonEmptoz A, Goutelle A, Girod G. Somatotroph adenoma manifested by galactorrhea without acromegaly. J Clin Endocrinol Metab 1985;61:451453.

10. Yamada S, Sano T, Stefaneanu L, Kovacs K, Aiba T, Sawano $S$ et al. Endocrine and morphological study of a clinically silent somatotroph adenoma of the human pituitary. J Clin Endocrinol Metab 1993;76:352-356. 